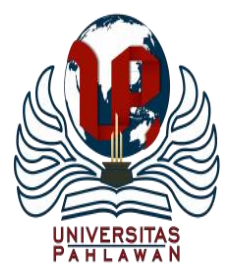

Edukatif : Jurnal Ilmu Pendidikan Volume 3 Nomor 3 Tahun 2021 Halm 1067 - 1074

EDUKATIF: JURNAL ILMU PENDIDIKAN

Research \& Learning in Education

https://edukatif.org/index.php/edukatif/index

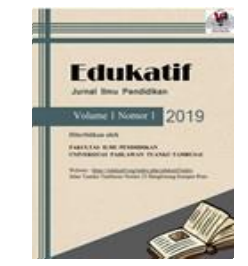

\title{
Pengembangan Modul Berbasis Inquiri Terstruktur pada Materi Larutan Penyangga pada SMA/MA
}

\author{
Diny Hazita Rahma ${ }^{1}$, Minda Azhar ${ }^{2}$ \\ Universitas Negeri Padang, Indonesia ${ }^{1,2}$ \\ E-mail : $\underline{\text { dinyhazita11@gmail.com }}{ }^{1}, \underline{\text { minda@fmipa.unp.ac.id }}^{2}$
}

\begin{abstract}
Abstrak
Berdasarkan bahan ajar larutan penyangga di mata pelajaran kimia SMA kelas XI semester dua. Proses belajar saat ini memakai metode saintifik yang mampu diganti melalui berbagai model proses belajar salah satunya yaitu inkuiri terstruktur. Penelitian ini memiliki tujuan yakni mengembangkan modul larutan penyangga berbasis inkuiri terstruktur dan menguji validitas dan praktikalitas modul yang dikembangkan. Macam-macam penelitian merupakan studi dan penyempurnaan atau Research \& Development (R\&D). Model pengembangan yaitu model Four-D (4-D) yang terdiri dari empat langkah: define (pendefenisisan),design (perancanangan), develop (pengembangan) dan disseminate (penyebaran). Penelitian tersebut terbatas kepada langkah pengembangan. Instrumen penelitian yaitu lembar validasi dan praktikalitas. Modul tersebut sudah divalidasi melalui 5 validator. Praktikalitas modul telah dilakukan uji penelitian oleh 2 orang pengajar Kimia dan 16 murid kelas XI SMAN 1 Pangkalan. Data validitas dan praktikalitas dianalisa memakai formula Aiken's $V$. Rata-rata Aiken's $V$ dari 5 orang validator adalah sejumlah 0,83 dengan kategori kevalidan tinggi dan uji praktikalitas guru dan siswa masing-masing 0,81 dan 0,82 dengan kategori kepraktisan tinggi. Hasil penelitian menunjukan bahwa modul larutan penyangga berbasis inkuiri terstruktur telah valid dan praktis ketika dipakai terhadap proses belajar-mengajar mata pelajaran kimia.
\end{abstract}

Kata Kunci: Modul berbasis inkuiri terstruktur, larutan penyangga , model 4-D

\section{Abstract}

The material for the buffer solution is chemistry subject matter for SMA class XI even semester. Current learning uses a scientific approach that can be filled with various learning models, one of which is structured inquiry. This study aims to develop a structured inquiry based viewer solution module and test the validity and practicality of the developed modules. This type of research is research and development or Research \& Development $(R \& D)$. The development model is a Four-D (4-D) model which consists of four steps: define, design, develop and disseminate. This study develops a developmental step. The research instrument was a validation sheet and practicality. This module is validated by 5 validators. The practicality of the module was tested by 2 Chemistry teachers and 16 students of class XI SMAN 1 Pangkalan. Data validity and practicality were analyzed using the Aiken $V$ formula. The average Aiken's $V$ of 5 validators was 0.83 with high validity and practicality tests for teachers and students respectively 0.81 and 0.82 with high practicality categories. The results showed that the structured inquiry-based buffer module was valid and practical for use in chemistry learning.

Keywords: Structured Inquiry Based Module, Buffer Solution,Model 4-D

Copyright (c) 2021 Diny Hazita Rahma, Minda Azhar

$\triangle$ Corresponding author

Email :dinyhazita11@gmail.com

DOI $\quad$ : https://doi.org/10.31004/edukatif.v3i3.512

ISSN 2656-8063 (Media Cetak)

ISSN 2656-8071 (Media Online)

Edukatif : Jurnal Ilmu Pendidikan Vol 3 No 3 Tahun 2021 p-ISSN 2656-8063 e-ISSN 2656-8071 
1068 Pengembangan Modul Berbasis Inquiri Terstruktur pada Materi Larutan Penyangga pada SMA/MA - Diny Hazita Rahma, Minda Azhar

DOI: https://doi.org/10.31004/edukatif.v3i3.512

\section{PENDAHULUAN}

Umumnya ilmu kimia menjabarkan mengenai tahapan, komposisi, sifat-sifat dan perubahan materi serta perubahan energi yang ada di lingkungan (Brady, 2012). Larutan penyangga merupakan materi pokok mata pelajaran kimia kelas XI SMA semester genap. Menurut kurikulum 2013 dengan alokasi waktu yang digunakaan ialah $1 \times 4$ jam pembelajaran. Materi pokok larutan penyangga ini mangulas tentang defenisi serta jenis-jenis larutan penyangga, keinginan kerja larutan penyangga, penjumlahan $\mathrm{pH}$ larutan penyangga serta penerapan larutan penyangga ketika kehidupan sehari-hari. Ketika proses belajar-mengajar, salah satu hal utama yang mendukung kesuksesan peserta didik ketika belajar ialah media pengajaran. Salah satu alat pengajaran yang bisa dipakai untuk membantu dalam pembelajaran adalah modul. Modul disebut juga sebagai suatu unit yang lengkap dimana terdapat seluruh rangkaian aktivitas belajar yang diatur sistematis supaya menolong murid menggapai beberapa tujuan yang diformulasikan secara rinci serta jelas (Nasution, 2011).

Penggunaan modul dalam proses pembelajaran memungkinkan peserta didik belajar dan menyelesaikan KD lebih cepat. Dengan demikian modul harus disajikan dengan menggunakan bahasa yang mudah dimengerti dan menarik. Penggunaan modul dalam proses pembelajaran dapat membantu peserta didik untuk belajar secara mandiri, dengan menggunakan modul peserta didik akan belajar lebih terarah dan sistematis. Modul adalah suatu cara pengorganisasian yang memperhatikan fungsi pendidikan (Mustika \& Sophia, 2019).

Untuk memperoleh bahan ajar yang sesuai, diperlukan pendekatan yang tepat. Menurut kurikulum 2013, pendekatan yang tepat dalam proses pembelajaran adalah pendekatan saintifik. Pendekatan saintifik diyakini sebagai jembatan perkembangan dan pengembangan sikap, keterampilan, dan pengetahuan peserta didik (Imas \& Berlin, 2014). Model pembelajaran inkuiri sesuai dengan Kurikulum 2013 dengan menerapkan pendekatan scientific (Permendikbud, 2016).

Berdasarkan tingkat keterlibatan guru dalam proses pembelajaran, model pembelajaran inkuiri terbagi atas inkuiri konfirmasi, inkuiri terstruktur, inkuiri terbimbing dan inkuiri terbuka (Colburn, 2000). Pada inkuiri terstruktur, peserta didik menyelidiki pertanyaan atau permasalahan yang diberikan oleh guru melalui suatu prosedur yang telah ditentukan dan menerima petunjuk dari setiap prosedur (Bell et al., 2005).

Penelitiaan sebelumnya menyatakan bahwa inkuiri terstruktur dapat meningkatkan pengetahuan peserta didik terutama pada daya ingat mereka terhadap materi pelajaran. Peserta didik masih dapat mengingat pelajaran meskipun telah berlalu selama 12 minggu (Schmid \& Bogner, 2015). Dalam inkuiri terstruktur, peserta didik melakukan penyelidikan secara langsung dan mengembangkan kemampuan dasarnya dalam penyelidikan, seperti melakukan pengamatan, hipotesis, mengumpulkan dan mengolah data, dan menarik kesimpulan (Zion \& Mendelovici, 2012).

Beberapa penelitian sebelumnya tentang inkuiri terstruktur, menyimpulkan bahwa menggunaan model pembelajaran inkuiri terstruktur dengan pendekatan saintifik dapat meningkatkan hasil belajar dan kemampuan berfikir kritis peserta didik (Handriani et al., 2017). Penelitian yang dilakukan oleh Raymon Suwardi (2017) menghasilkan bahwa aktifitas peserta didik dalam proses pembelajaran berbasis inkuiri terstruktur dapat meningkatkan pemahaman dan prestasi belajar peserta didik. Sejalan dengan itu, penggunaan LKS berbasis inkuiri terstruktur berdampak positif terhadap keterampilan generik dan dapat meningkatkan kemandirian peserta didik dalam mengkontruksi pemikirannya pada proses pembelajaran yang dilakukan (Meiry \& Ahmad, 2019).

Dari penelitian yang sudah dilakukan sebelumnya, didapatkan hasil bahwa penggunaan model pembelajaran inkuiri terstruktur dalam proses pembelajaran memiliki dampak positif. Salah satu bahan ajar yang mendukung penerapan model pembelajaran ini adalah modul. Berdasarkan latar belakang di atas, maka pengembangan bahan ajar berupa modul berbasis inkuiri terstruktur penting untuk dilakukan. Penelitian ini bertujuan untuk menghasilkan modul larutan penyangga berbasis inkuiri terstruktur yang valid dan praktis digunakan dalam pembelajaran kimia untuk kelas XI Sekolah Menengah Atas. 
1069 Pengembangan Modul Berbasis Inquiri Terstruktur pada Materi Larutan Penyangga pada SMA/MA - Diny Hazita Rahma, Minda Azhar

DOI: https://doi.org/10.31004/edukatif.v3i3.512

\section{METODE}

Metode penelitian yang dipakai di penelitian dan pengembangan atau Researchand Development $(R \& D)$. Penelitian R\&D yakni metode penelitian yang dipakai untuk menunjukkan barang penting. Penelitian tersebut dilakukan untuk menyempurnakan modul larutan penyangga berbasis inkuiri terstruktur terhadap kelas XI SMA dan mengungkapkan ukuran validitas serta praktikalitas modul tersebut. Penelitian ini terbatas hingga tahapan uji validitas dan praktikalitas terhadap modul yang sedang disempurnakan. Subjek penelitian ini berjumlah 3orang dosen kimia FMIPA UNP, 2 orang guru kimia dan 16 orang murid kelas XI MIPA 1 SMAN 1 Pangkalan Koto Baru. Data yang dianalisis menggunakan formula Aiken's V:

$$
\begin{aligned}
& V=\frac{\sum s}{n(C-1)} \\
& s=r-l o
\end{aligned}
$$

\section{Keterangan:}

Lo =Skor paling rendah dalam kategori (penyekoran) (skor:1)

$c \quad=$ Banyaknya kategori yang dipilih penilai (skor: 5)

$r \quad=$ Skor yang diperoleh dari penilai

$n \quad=$ Banyak penilai

$s \quad=$ Skor diperoleh dikurangi dengan skor paling rendah (Hendryadi, 2017)

Nilai validitas dan praktikalitas berdasarkan skala Aiken's $V$ memiliki kategori dalam Tabel 1 (Retnawati, 2016).

Tabel 1. Kategori Keputusan mengikuti skala Aiken's $V$

$\begin{array}{cc}\text { Interval } & \text { Kategori } \\ \leq 0,4 & \text { Kurang } \\ 0.4<\mathrm{V} \leq 0.8 & \text { Sedang } \\ 0.8<\mathrm{V} & \text { Valid }\end{array}$

Modul dikembangkan menggunakan model 4-D yang terbagi melalui tahapan define (pengartian), design (desain),develop(penyempurnaan)dan disseminate (penyebaran).

Sejumlah langkah yang dikerjakan dalam penelitian ini diantaranya adalah: 1) tahap define (pengartian), tahap define terdiri dari 5 langkah yaitu analisis awal akhir, analisis siswa, analisis tugas, analisis konsep dan analisis tujuan pembelajaran; 2) tahap design (desain), tahap ini bertujuan untuk merancang modul larutan penyangga berbasis inkuiri terstruktur untuk kelas XI SMA. Penulisan modul umumnya dilakukan melalui panduan pengembangan media pengajaran ; 3) tahap develop (pengembangan), tahap develop bertujuan untuk menghasilkan modul larutan penyangga berbasis inkuiri terstruktur untuk kelas XI SMA yang valid dan praktis. Pada tahap ini dilakukan uji validitas, revisi dan uji praktikalitas.

Instrumen yang digunakan pada penelitian ini adalah angket validitas dan praktikalitas. Angket validitas ditujukan kepada dosen kimia UNP dan guru kimia SMA. Angket praktikalitas diberikan kepada guru kimia dan siswa SMA. Angket validitas digunakan untuk menilai modul dari aspek kelayakan isi, penyajian, kebahasaan dan kegrafisan. Setelah dilakukan uji validitas terhadap modul yang dikembangkan, selanjutnya modul dilakukan revisi sesuai saran yang disampaikan dari validator. Sesudah diganti, berikutnya akan dikerjakan uji praktikalitas modul yang berguna mengetahui kepraktisan pemakaian dari modul yang dikembangkan.

\section{HASIL DAN PEMBAHASAN}

Data hasil penelitian didapatkan setelah melakukan penelitian dan pengambilan data di SMAN 1 Pangkalan. Berdasarkan tujuan penelitian dan jenis penelitian R\&D (Research and Development) memakai metode penyempurnaan 4-D, maka dihasilkan produk berjenis modul berbasis inkuiri terstruktur terhadap 
pembelajaran mengenai larutan penyangga yang diajarkan terhadap kelas XI. Model pengembangan 4-D terdiri dari beberapa tahap yaitu define (pendefinisian), design (desain), develop (penyempurnaan), dan disseminate (penyebaran). Keempat tahapan tersebut mampu diuraikan sebagai berikut:

Tahap pertama yaitu Define (Pengartian) terdari analisis awal akhir melalui analisa tersebut dilakukan wawancara terhadap pengajar kimia supaya mengetahui permasalahan yang ada ketika proses belajarmengajar. melalui data wawancara terhadap guru SMA Adabiah 2 Padang diperoleh hasil berikut: (1) Sebagian murid sering sulit mengerti materi larutan penyangga. Disebabkan media pengajaran di larutan penyangga bersifat acak dan cukup kompleks untuk dipahami karena memiliki hubungan materi satu dengan materi yang lain yang cukup erat serta memiliki hitung-hitungan sehingga sulit dipahami oleh murid. (2) Peserta didik menggunakan media pengajaran berupa buku paket. Materi yang disajikan pada modul belum menuntun peserta didik menemukan konsep; (3) Bahan ajar yang digunakan belum memuat tahapan-tahapan model pembelajaran yang digunakan guru. Yang kedua adalah analisa pada murid diperoleh gambaran sifat murid yang diliputi keahlian akademik dan kemampuan kognitif peserta didik. Berdasarkan hasil angket observasi yang diisi oleh murid didapatkan gambaran berikut ini:1) Sebanyak 66,7\% peserta didik SMA Adabiah 2 Padang kesulitan memahami materi larutan penyangga. 2) Peserta didik menyukai bahan ajar yang mudah dipahami, menarik, berwarna dan dilengkapi gambar. 3) Analisis tugas melalui silabus Permendikbud no. 59 tahun 2014, media pengajaran larutan penyangga berada di kompetensi dasar (KD) 3.12 dan 4.12 yaitu menjabarkan keinginan kerja, penjumlahan $\mathrm{pH}$ dan karakter larutan penyangga di tubuh makhluk hidup dan industri. Membentuk larutan penyangga melalui pH tertentu. 4) Analisis konsep yaitu konsep-konsep pada materi ini disusun dalam bentuk hirearki konsep. Adapun konsep- konsep tersebut adalah cairan penyangga asam, cairan penyangga basa, $\mathrm{pH}$ cairan penyangga, peranan cairan penyangga. Konsep-konsep tersebut dianalisis berdasarkan buku-buku kimia perguruan tinggi dan buku kimia SMA yang relevan. Kelima adalah analisis tujuan pembelajaran disusun melalui indikator raihan kompetensi. Tujuan pembelajaran yang sudah disusun adalah berdasarkan metode pembelajaran inkuiri terstruktur melalui pencarian informasi oleh berbagai sumber belajar, melakukan analisa sederhana dan menganalisa informasi, murid diharapkan aktif berhubungan ketika proses pembelajaran, mempunyai karakter selalu penasaran, teliti ketika mengerjakan pengamatan, bertanggung jawab ketika penyampaian angapan, menjawab pertanyaan, menyampaikan saran dan kritik.

Tahap kedua yaitu Design (Perancangan), tahapan perancangan mempunyai tujuan agar mendesain modul larutan penyangga yang akan diperbaiki. Beberapa langkah yang dikerjakan terhadap tahapan perancangan adalah pengisian angket oleh siswa SMAN 1 Pangkalan Koto Baru. Pengisian angket tersebut memiliki tujuan supaya mengerti media pengajaran yang diharapkan oleh murid pada pembelajaran larutan penyangga agar siswa mudah memahami materi tersebut. berdasarkan pengisian angket diperoleh informasi bahwa siswa menginginkan bahan ajar yang mudah dipahami, memiliki tampilan menarik disertai dengan warna dan gambar. Modul larutan penyangga yang telah dirancang terdiri dari; 1) cover; 2) kata pengantar; 3) daftar isi; 4) daftar gambar; 5) panduan pemakaian modul; 6) kompetensi inti; 7) kompetensi dasar; 8) indikator raihan kompetensi; 9) tujuan belajar-mengajar; 10) peta konsep; 11) pendahuluan; 12) lembar kegiatan; 13) lembar kerja; 14) lembar tes; 15) kunci lembar kegiatan; 16) kunci lembar kerja; 17) kunci lembar tes. cover modul, dan kunci lembar kegiatan mampu diamati pada Gambar 1 sampai Gambar 2. 
1071 Pengembangan Modul Berbasis Inquiri Terstruktur pada Materi Larutan Penyangga pada SMA/MA - Diny Hazita Rahma, Minda Azhar

DOI: https://doi.org/10.31004/edukatif.v3i3.512
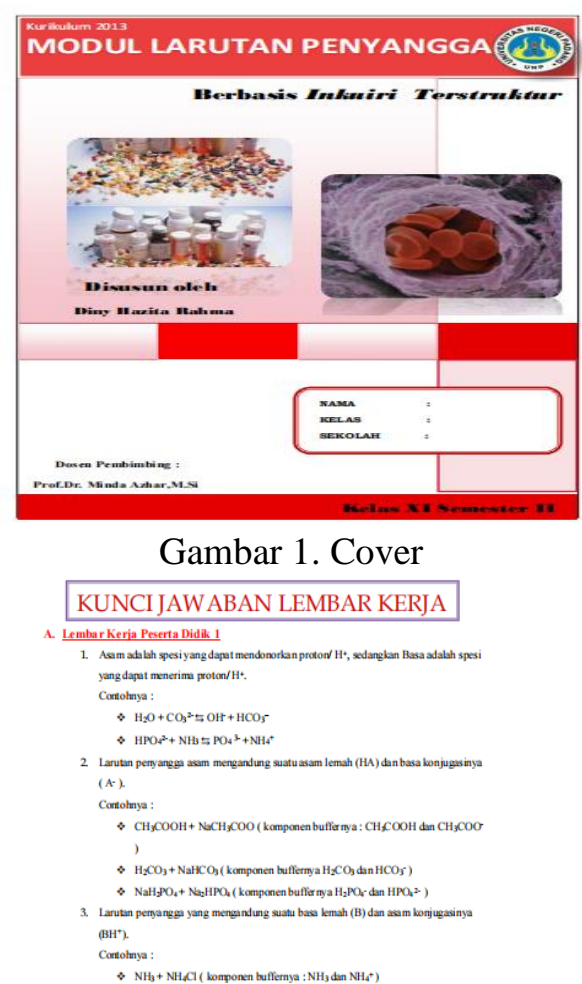

Gambar 2. Kunci lembar kerja

Tahap ketiga adalah tahapan develop (Penyempurnaan) tahap ini terbagi dua yaitu uji validitas dan uji praktikalitas. Uji validitas bertujuan untuk mengungkapkan validitas dari modul yang dikembangkan. Validasi dilakukan oleh tiga orang dosen dan dua orang guru kimia. Tahap revisi bertujuan untuk memperbaiki modul yang dianggap masih kurang tepat oleh validator sebelum produk diujicoba. Modul yang sudah diperbaiki kemudian diberikan kembali kepada validator untuk didiskusikan lebih lanjut sebelum diuji coba. Revisi dihentikan apabila validator sudah menyatakan modul yang dibuat sudah valid. Data validitas ditunjukkan melalui Gambar 3.

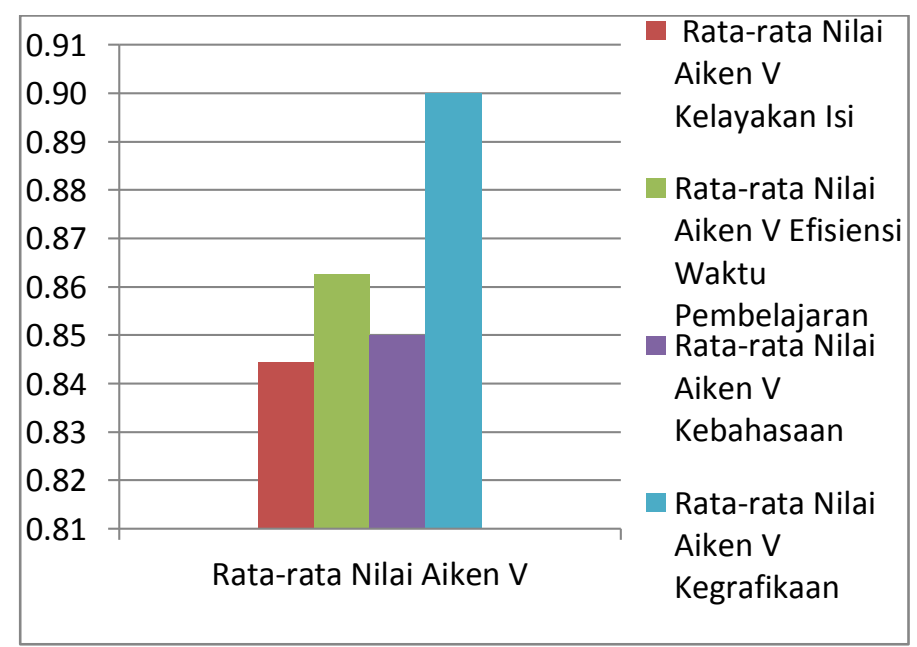

Gambar 3. Hasil validasi modul

melalui hasil penilaian oleh kelima validator kepada modul yang diperbaiki didapatkan rata-rata indeks Aikens $\mathrm{V}$ yaitu 0,86 yang menunjukkan bahwa modul yang dikembangkan memiliki kevalidan tinggi dan telah menyelesaikan komponen-komponen yang ada di lembar validasi. Suatu produk yang sedang dikembangkan 
1072 Pengembangan Modul Berbasis Inquiri Terstruktur pada Materi Larutan Penyangga pada SMA/MA - Diny Hazita Rahma, Minda Azhar

DOI: https://doi.org/10.31004/edukatif.v3i3.512

bisa dinyatakan valid apabila sama terhadap teori yang sempurna dan seluruh komponen saling berkaitan secara sering (Rochmad, 2012).

Pada komponen kelayakan isi memiliki rata-rata indeks Aikens $\mathrm{V}$ rata-rata sebesar 0,84 dengan kategori kevalidan tinggi. Hal ini menunjukkan bahwa modul yang dikembangkan telah valid dan sudah sesuai dengan kompetensi inti, kompetensi dasar, indikator raihan kompetensi dan tujuan proses belajar-mengajar yang akan diraih. Oleh sebab itu, pertanyaan yang terdapat pada modul tidak memiliki makna ambigu dan membantu peserta didik menemukan konsep larutan penyangga. Suatu modul dapat dikatakan layak untuk digunakan apabila sesuai dengan kompetensi pembelajaran pada kurikulum 2013 yang sudah ditetapkan.

Komponen penyajian modul mempunyai rata-rata indeks Aikens $\mathrm{V}$ sebesar 0,86 melalui kategori kevalidan yang sangat besar. Hal ini menunjukan kalau modul larutan penyangga yang dikembangkan telah disusun secara sistematik sesuai dengan komponen-komponenpenyusunan modul. Komponen kebahasaan modul yang dikembangkan memiliki rata-rata indeks Aikens $\mathrm{V}$ sebesar 0,85 dengan kategori kevalidan yang tinggi. Hal ini dikarenakan modul yang dikembangkan telah menggunakan bahasa yang komunikatif, dan sesuai dengan kaidah ejaan bahasa Indonesia. Selain itu, pertanyaan-pertanyaan yang diajukan dalam modul sudah jelas dan konsisten dalam menggunakan simbol/lambang Komponen kegrafisan modul yang dikembangkan mempunyai rata-rata indeks Aikens V sejumlah 0,90 berarti kategori kevalidan sangat besar. disebabkan gambar dan jenis huruf yang ditemukant di modul telah bisa teramati dan bisa terbaca dengan jelas dan modul yang diganti sudah diatur oleh segi tata letak hingga pemilihan warna mampu membuat murid senang.

Tahapan kedua yaitu uji praktikalitas produk dilakukan kepada guru dan siswa SMA 1 Pangkalan Koto Baru kelas XI MIA 1. Uji praktikalitas ini bertujuan untuk mengetahui praktikalitas modul larutan penyangga yang dikembangkan meliputi manfaat, kemudahan penggunaan, dan efisiensi waktu pembelajaran dengan menggunakan modul tersebut. Kepraktisan modul dilakukan dengan menggunakan angket praktikalitas. Hasil praktikalitas ditunjukkan melalui gambar 4.

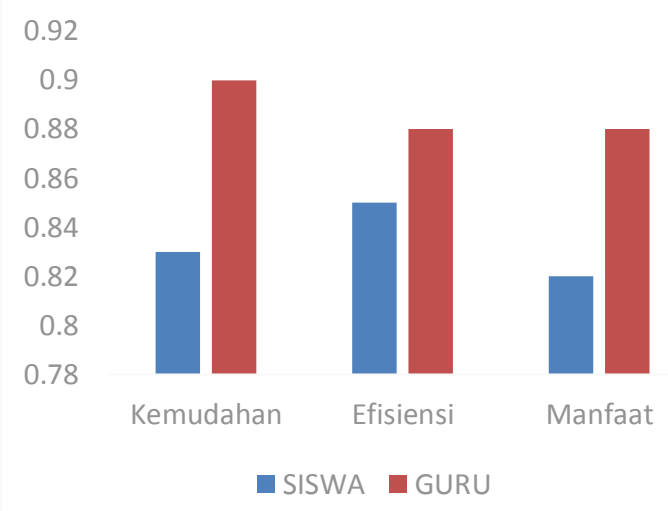

Gambar 4. Hasil praktikalitas guru dan siswa

Pada komponen kemudahan penggunaan modul memperoleh rata-rata indeks Aikens V sejumlah 0,90 bagi guru dan 0,83 bagi peserta didik melalui kategori besar. Ini berarti memperlihatkan bahwa modul berbasis inkuiri terstruktur terhadap materi larutan penyangga yang sedang disempurnakan sudah menyediakan petunjuk penggunaan yang mudah dipahami. Selain itu, telah menggunakan bahasa yang mudah dimengerti dan komunikatif, serta memiliki ukuran praktis dan mudah dibawa.

Komponen efisiensi waktu pembelajaran diperoleh indeks Aikens $\mathrm{V}$ rata-rata sebesar 0,88 untuk guru dengan kategori kevalidan tinggi dan 0,85 untuk peserta didik melalui kategori kevalidan tinggi. Ini berarti menunjukan kalau modul berbasis inkuiri terstruktur terhadap media pengajaran cairan penyangga yang disempurnakan membantu pembelajaran menjadi efisien. 
1073 Pengembangan Modul Berbasis Inquiri Terstruktur pada Materi Larutan Penyangga pada SMA/MA - Diny Hazita Rahma, Minda Azhar

DOI: https://doi.org/10.31004/edukatif.v3i3.512

Dari segi manfaat diperoleh rata-rata indeks Aiken $\mathrm{V}$ sejumlah 0,88 dari guru dan 0,82 dari peserta didik menunjukkan kategori tinggi. Hal ini menunjukan kalau modul yang disempurnakan dapat bermanfaat bagi guru dan peserta didik ketika pelaksanaan pembelajaran, karena dapat membantu guru dalam menanamkan konsep terhadap murid dan meringankan murid untuk mengerti arti larutan penyangga serta meningkatkan minat belajar peserta didik dapat dilihat pada Gambar 4 diatas.

Berdasarkan hasil pengolahan data yang telah dilakukan, dapat disimpulkan bahwa modul larutan penyangga berbasis inkuiri terstruktur yang dikembangkan memiliki kevalidan dan kepraktisan dengan kategori sangat tinggi. Hal ini sesuai dengan penelitian yang dilakukan oleh Sholehah \& Azhar (2019) didapatkan hasil bahwa pengembangan modul pada materi bentuk molekul berbasis inkuiri terstruktur memiliki kevalidan dan kepraktisan sangat tinggi. Penelitian yang dilakukan oleh Sundami \& Azhar (2019) didapatkan hasil bahwa modul kesetimbangan kimia yang dikembangkan memiliki kategori kevalidan dan kepraktisan sangat tinggi. Selajan dengan itu, penelitian yang dilakukan oleh Sari \& Azhar (2019) mendapatkan hasil modul perhitungan rumus kimia dan persamaan reaksi berbasis inkuiri terstruktur juga memiliki kevalidan dan kepraktisan sangat tinggi.

Modul larutan penyangga berbasis inkuiri tersturktur yang dikembangkan memiliki kategori kevalidan dan kepraktisan yang sangat tinggi. Sehingga modul ini dapat dijadikan bahan ajar alternatif yang digunakan dalam proses pembelajaran sesuai dengan tuntutan kurikulum 2013 yang menerapkan pendekatan scientific. Keterbatasan dalam penelitian ini karena penelitian dilakukan pada masa pandemic Covid-19. Akibatnya pembelajaran di sekolah membagi siswa menjadi dua shift dalam melakukan proses pembelajaran. Hal ini mengakibatkan pelaksanaan penelitian memakan waktu yang cukup lama.

\section{KESIMPULAN}

Melalui penelitian yang telah dikerjakan, didapatkan bahwa modul larutan penyangga berbasis inkuiri terstruktur bagi kelas XI SMA memakai model pengembangan 4-D. Modul yang disempurnakan memiliki tingkat kevalidan dan kepraktisan sangat tinggi sehingga dapat digunakan dalam proses pembelajaran

\section{DAFTAR PUSTAKA}

Bell, R., Smetana, L., \& Binns, I. (2005). Simplifying inquiry instruction. The Science Teacher, 72(7), 30-33.

Brady, J. E. (2012). Chemistry The Molecular Nature Of Matter. John Wiley \& Sons, Inc.

Colburn, A. (2000). An Inquiry Primer. Science Scope, 23(6), 42-44.

Handriani, L. S., Harjono, A., \& Doyan, A. (2017). Pengaruh Model Pembelajaran Inkuiri Terstruktur dengan Pendekatan Saintifik Terhadap Kemampuan Berpikir Kritis dan Hasil Belajar Fisika Siswa. Jurnal Pendidikan Fisika Dan Teknologi, 1(3), 210. https://doi.org/10.29303/jpft.v1i3.261

Hendryadi, H. (2017). Validitas Isi: Tahap Awal Pengembangan Kuesioner. Jurnal Riset Manajemen Dan Bisnis (JRMB) Fakultas Ekonomi UNIAT, 2(2), 169-178. https://doi.org/10.36226/jrmb.v2i2.47

Imas, K., \& Berlin, S. (2014). Sukses Mengimplementasikan Kurikulum 2013. Kata Pena.

Meiry, N., \& Ahmad, K. (2019). Efektivitas LKS Konsep Sistem Pernafasan Berbasis Inkuiri Terstruktur Dengan Terbimbing Pada Kemampuan Generik Sains Siswa. 7(1), 48-57.

Mustika, N., \& Sophia, A. (2019). Pengembangan Modul English In Analyzer Dalam Peningkatan Kemampuan Berbahasa Inggris Bagi Mahasiswa Analis Kesehatan. Jurnal Ilmu Pendidikan, 1(3), 294302. https://edukatif.org/index.php/edukatif/index

Nasution, S. (2011). Berbagai Pendekatan Dalam Proses Belajar Mengajar. Bumi Aksara. 
1074 Pengembangan Modul Berbasis Inquiri Terstruktur pada Materi Larutan Penyangga pada SMA/MA - Diny Hazita Rahma, Minda Azhar

DOI: https://doi.org/10.31004/edukatif.v3i3.512

Permendikbud. (2016). Peraturan Menteri Pendidikan dan Kebudayaan Republik Indonesia Nomor 22 Tahun 2016 tentang Standar Proses Pendidikan Dasar dan Menengah. Journal of Chemical Information and Modeling, 53(9), 1689-1699.

Raymon Suwardi. (2017). Peningkatan Prestasi Belajar IPA Peserta Didik Kelas VIII Melalui Pembelajaran Inkuiri Terstruktur. Jurnal Pembelajaran Sains, 1(2009), 27-34.

Retnawati, H. (2016). Analisis Kuantitatif Instrumen Penelitian. Parama Publishing.

Rochmad. (2012). Desain Model Pengembangan Perangkat Pembelajaran Matematika. Kreano: Jurnal Matematika Kreatif-Inovatif, 3(1), 59-72. https://doi.org/10.15294/kreano.v3i1.2613

Sari, M. P., \& Azhar, M. (2019). Pengembangan Modul Perhitungan Rumus Kimia dan Persamaan Reaksi Berbasis Inkuiri Terstruktur dengan Tiga Level Representasi untuk Kelas X SMA/MA. Edukimia, 1(2), 46-52. https://doi.org/10.24036/ekj.v1.i2.a20

Schmid, S., \& Bogner, F. X. (2015). Effects of Students' Effort Scores in a Structured Inquiry Unit on LongTerm Recall Abilities of Content Knowledge. Education Research International, 2015, 1-11. https://doi.org/10.1155/2015/826734

Sholehah, P. S., \& Azhar, M. (2019). Pengembangan Modul Bentuk Molekul Berbasis Inkuiri Terstruktur Dengan Penekanan Pada Level Submikroskopik Menggunakan Pemodelan Untuk Kelas X SMA. EduKimia, 1(1), 60-69. https://doi.org/10.24036/ekj.v1i1.104088

Sundami, N., \& Azhar, M. (2019). Pengembangan Modul Kesetimbangan KimiaBerbasis Inkuiri Terstruktur dengan Menggunakan Tiga Level Representasi Kimia Untuk Siswa Kelas XI SMA. EduKimia, 1(1), 1120. https://doi.org/10.24036/ekj.v1i1.104018

Zion, M., \& Mendelovici, R. (2012). Moving from structured to open inquiry: Challenges and limits. Science Education International, 23(4), 383-399. 